\title{
Standardization and Physico-Chemical Properties of Custard Apple Soya Milk Shake
}

\author{
Ramesh Avhad, Vaibhav Patil* and Navnath Sarode \\ Department of Food Science and Technology, Shramshakti College of Food Technology, \\ Maldad - 422 608, A. Nagar, India \\ *Corresponding author
}

\section{A B S T R A C T}

Keywords

Soya Milk,

Custard apple pulp,

Soya milk shake,

Sensory evaluation,

Physico-chemical

evaluation.

Article Info

Accepted:

25 January 2017

Available Online:

10 February 2017
Soya milk was used as alternative of cow and buffalo milk due to problems with intolerance and allergy. Soya milk shake was prepared from different proportions of soya milk standardized with cardamom essence and custard apple pulp i.e. $\left(\mathrm{T}_{1}\right)$ 95:05, $\left(\mathrm{T}_{2}\right)$ 90:10 and $\left(\mathrm{T}_{3}\right)$ 85:15. The overall acceptability of custard apple milk shake of treatments $\mathrm{T}_{1}, \mathrm{~T}_{2}$ and $\mathrm{T}_{3}$ were $8.16,8.35$ and 7.65 , respectively determined by sensory evaluation. It was observed that the custard apple soya milk shake prepared from 90 parts of soya milk and 10 parts of custard apple pulp i.e. treatment $T_{2}$ was more acceptable than other treatments and ranked between like very much to dislike very much. The products were analysed for physico-chemical properties likewise TSS, viscosity, Specific Gravity, $\mathrm{pH}$, acidity, protein, fat, total sugar and ash.

\section{Introduction}

The demand for alternatives to dairy products is growing due to problems with intolerance and allergy, desire for vegetarian alternatives and so on and hence the interest in soya-based foods has developed. Soya milk is one of the popular traditional products in China and other Asian countries consumed as a nutritious and economical protein food. Consumers preferred soya milk mainly as an important replacer of cow milk due to lactose intolerance or allergic reaction to cow's milk and as a low cost source of good quality protein and energy. They contain no cholesterol and little or no saturated fat (Jooyandeh, 2011). Recent advancements in science has resulted several soya milk products. It is essentially a water extract of soybeans, and contains all of the components of the bean, except for some insoluble fiber removed during processing called okara (Kwok and Niranjan, 1995; Mullin et al., 2001; Akintunde and Akintunde, 2002; Lakshmanan et al., 2006). Soya milk composition varies depending on processing conditions and bean variety and in general contains about $8-10 \%$ total solids, $3.6 \%$ protein, $2.0 \%$ fat, $2.9 \%$ carbohydrates and $0.5 \%$ ash (Liu, 1997). Soya milk shake is obtained by freezing a mix very similar to soft serve ice cream mix and speedy mixing of the 
frozen product to make it pourable and generate foam in it.

Blending soya milk with different fruits to formulate tasty and palatable products is gaining importance. Custard apple (Annona squamosa L.) is popularly called as sitaphal in South India and sharifa in North India. A considerable portion of the produce goes waste because of lack of primary processing and other factors.

Custard apple is rich in carbohydrates and good source of proteins and minerals like calcium, phosphorus and iron. Its calorific value ranges from 822 to $1050 \mathrm{kcal}$ per $\mathrm{kg}$ as compared with $741 \mathrm{kcal}$ per $\mathrm{kg}$ of mango (Rao, 1974). Custard apple is considered as one of the delicious and nutritionally valuable fruit. It contains about $28-55 \%$ of edible portion consisting of $73.30 \%$ moisture, $1.60 \%$ protein, $0.30 \%$ fat, $0.70 \%$ mineral matter, $23.90 \%$ carbohydrates (Nissen et al., 1988). The both soya milk and custard apple pulp are easy to digest and they can be consumed easily by children and people of all ages (Kirtikar and Basu, 1955; Jooyandeh, 2011). So, an attempt was made to prepare soya milk shake blended with varying amount of custard apple pulp. The sensory and Physicochemical characteristics of the finished product were also studied.

\section{Materials and Methods}

All the raw materials i.e. soyabean, custard apple, sugar \& cardamom essence were purchased from local market of Sangamner, Dist- Ahmednagar. Soya milk was extracted and standardized with $0.5 \%$ cardamom essence. The pulp was extracted by fruit and stored at $15-20^{\circ} \mathrm{C}$ temperature. The stabilizing agent such as sodium alginate was used as stabilizer. The custard apple soya milk shake was prepared as per the method described by Poul et al., (2009) with slight modification.
The physic-chemicals properties of final product were determined in Food Chemistry and Nutrition laboratory of Shramshakti college of Food Technology, Maldad.

\section{Product treatments}

The custard apple soya milk shake, blends of soya milk and custard apple pulp were as follows.

$\mathrm{T}_{1} \quad 95$ part of soya milk +05 part of custard apple pulp

$\mathrm{T}_{2} \quad 90$ part of soya milk +10 part of custard apple pulp

T3 85 part of soya milk +15 part of custard apple pulp

\section{Preparation of soya milk}

The soybeans were cleaned to remove dirt's and impurities. Water was added to the beans in the ratio of 1.3 (beans to water) and the beans were allowed to soak for $10 \mathrm{hrs}$. After $10 \mathrm{hrs}$ drained and the soybeans were then dehuled and the chaff removed by adding water and decanting. Milling was done using a mixture. About 3 parts of water was added to the slurry and $0.5 \%$ cardamom essence was added. The mixture was allowed to pasteurized at $68^{\circ} \mathrm{C}$ for $30 \mathrm{~min}$. It was then bottled while still hot and allowed to cools as per the method described by Oloye (2014).

\section{Preparation of custard apple pulp}

Good quality fully eye opened, ripened but firm fruits having uniform green colour, with creamy whitish pulp and pleasant flavour were selected. After washing manual peeling was done, the pulp and seeds were separated by rubbing the pulpy seeds on stainless steel wire mesh. The pulp was filtered through muslin cloth. Then pulp was pasteurized at $85^{\circ} \mathrm{C}$ for $30 \mathrm{~min}$ and packed in high density polythene pouches. The pulp was stored at 
$15-20^{\circ} \mathrm{C}$ temperature in refrigerator for $2 \mathrm{hrs}$. and used after addition of sodium alginate as per method described by Poul et al., (2009).

\section{Preparation of custard apple soya milk} shake

Custard apple soya milk shake was prepared as per method described by Sharma and Gupta (1978) with slight modification. It is shown in (fig 1).

\section{Sensory evaluation}

The sensory quality of product was evaluated by a panel of 10 judges selected from the staff of Department of Food Science and Technology, Food Chemistry and Nutrition, Food Engineering and Food Microbiology of Shramshakti College of Food Technology, Maldad, using 9 point Hedonic scale as described by Ranganna (1999).

\section{Physico-chemical analysis}

\section{Physical properties}

TSS of custard apple soya milk shake was determined with the help of Erma hand refractometer described in A.O.A.C. (1990). Specific gravity and density by specific gravity bottle method described in A.O.A.C. (1990), Viscosity determined as per Ostwald's viscometer method described by Ranganna (1999), and $\mathrm{pH}$ was measured using digital $\mathrm{pH}$ meter.

\section{Chemical analysis}

Protein content of custard apple soya milk shake was determined by micro-Kjeldhal method described in Ranganna (1999), fat content by Gerber's method described in FSSAI (2015), Total sugar determined as per phenol-sulphuric method described in Thimmaiah (2012). Ash and titratable acidity was determined by ISI (1961).

\section{Results and Discussion}

Sensory evaluation of custard apple milk shake: The soya milk shake fortified with different proportion of custard apple pulp were subjected to sensory evaluation for overall acceptability i.e. colour and appearance, flavour, taste and consistency by trained judges, through 9 point hedonic scale and is presented in table 1 .

The mean score for colour and appearance of different treatments of custard apple soya milk shake i.e. $\mathrm{T} 1, \mathrm{~T}_{2}$ and $\mathrm{T}_{3}$ were $8.22,8.25$ and 8.14, respectively. Treatment $\mathrm{T}_{2}$ got highest score as compared to treatment $\mathrm{T}_{1}$ and $T_{3}$. In a treatment $T_{2}$ contained 10 per cent of custard apple pulp which was increase the colour and appearance of the soya milk shake. There were slight differences amongst all treatments for colour and appearance score.

Score for the flavour of treatment $\mathrm{T}_{1}, \mathrm{~T}_{2}$ and $\mathrm{T}_{3}$ were $7.72,7.91$ and 8.00 , respectively. The height score for flavour was $\mathrm{T}_{3}$ and lowest score $\mathrm{T}_{1}$. The hedonic scale were ranked between like very much to dislike very much. It was observed above findings, if increased the percentage of custard apple pulp in the blend, the flavour of soya milk shake also increased. Changes of product flavour may be due to pleasant flavour of custard apple pulp which enhanced the flavour of soya milk shake.

Taste score for treatment $\mathrm{T}_{1}, \mathrm{~T}_{2}$ and $\mathrm{T}_{3}$ was $8.10,8.40$ and 7.22, respectively. The taste of treatment $\mathrm{T}_{2}$ was most acceptable as compared to treatment $T_{1}$ and $T_{3}$. In $a$ treatment $\mathrm{T}_{2}$ got acceptable taste of custard apple by sensory panel member.

Score for the consistency of treatment $\mathrm{T}_{1}, \mathrm{~T}_{2}$ and $\mathrm{T}_{3}$ were $8.18,8.51$ and 7.01 , respectively. Consistency of treatment $\mathrm{T}_{2}$ was better than other treatments. If increases the percentage 
of custard apple pulp beyond 10 per cent in blend, also increased consistency of product and decreased the score.

The mean score for overall acceptability of custard apple soya milk shake of treatment $\mathrm{T}_{1}$, $\mathrm{T}_{2}$ and $\mathrm{T}_{3}$ were 8.16, 8.35 and 7.65 respectively. Treatment $\mathrm{T}_{2}$ got highest score for overall acceptability by judges due to it colour, flavour and consistency. Therefore treatment $\mathrm{T}_{2}$ was most acceptable. So, blending of 10 per cent custard apple pulp for soya milk shake was more acceptable than others.

\section{Physico-chemical evaluation}

Physical properties: Physical properties of treatment $T_{1}, T_{2}$ and $T_{3}$ were studied and is shown in table 2 .

TSS: The TSS content of custard apple soya milk shake was determined with the help of Erma hand refractometer. The prism of refractometer was washed with water and wiped dry after each reading of treatments and maintained up to $16^{\circ}$ brix to each treatment.

Viscosity: Viscosity was determined by Ostwald's viscometer method. The viscosity of treatment $\mathrm{T}_{1}, \mathrm{~T}_{2}$ and $\mathrm{T}_{3}$ were $5.67 \mathrm{cp}$, $8.18 \mathrm{cp}$ and $13.58 \mathrm{cp}$, respectively. The viscosity of treatment $T_{2}(8.18 \mathrm{cp})$ was higher than treatment $\mathrm{T}_{1}(5.67 \mathrm{cp})$ and less than treatment $\mathrm{T}_{3}(13.58 \mathrm{cp})$. It was observed that as the part of custard apple pulp increased with also increases viscosity of product.

Table.1 Score for overall acceptability of custard apple soya milk shake

\begin{tabular}{cccccc}
\hline Treatment & $\begin{array}{c}\text { Colour and } \\
\text { appearance }\end{array}$ & Flavour & Taste & Consistency & $\begin{array}{c}\text { Overall } \\
\text { acceptability }\end{array}$ \\
\hline $\mathrm{T}_{1}$ & 8.22 & 7.72 & 8.10 & 8.18 & 8.16 \\
$\mathrm{~T}_{2}$ & 8.25 & 7.91 & 8.40 & 8.51 & 8.35 \\
$\mathrm{~T}_{3}$ & 8.14 & 8.00 & 7.22 & 7.01 & 7.62 \\
\hline
\end{tabular}

Table.2 Physical properties of custard apple soya milk shake

\begin{tabular}{cccccc}
\hline Treatment & $\begin{array}{c}\text { TSS } \\
\left({ }^{\circ} \text { Brix }\right)\end{array}$ & $\begin{array}{c}\text { Viscosity } \\
(\mathrm{cp})\end{array}$ & $\begin{array}{c}\text { Specific } \\
\text { gravity }\end{array}$ & $\begin{array}{c}\text { Density } \\
(\mathrm{gm} / \mathrm{ml})\end{array}$ & $\begin{array}{c}\mathrm{pH} \\
(\%)\end{array}$ \\
\hline $\mathrm{T}_{1}$ & 16 & 5.67 & 1.0624 & 1.1364 & 6.30 \\
$\mathrm{~T}_{2}$ & 16 & 8.18 & 1.0626 & 1.1366 & 6.27 \\
$\mathrm{~T}_{3}$ & 16 & 13.58 & 1.0628 & 1.1368 & 6.25 \\
\hline
\end{tabular}

Table.3 Chemical composition of custard apple soya milk shake

\begin{tabular}{cccccc}
\hline Treatment & Protein $(\%)$ & Fat $(\%)$ & $\begin{array}{c}\text { Total sugar } \\
(\%)\end{array}$ & Ash $(\%)$ & Acidity $(\%)$ \\
\hline $\mathrm{T}_{1}$ & 3.85 & 1.6 & 15.75 & 0.72 & 0.14 \\
$\mathrm{~T}_{2}$ & 3.50 & 1.2 & 16.92 & 0.75 & 0.16 \\
$\mathrm{~T}_{3}$ & 2.80 & 1.0 & 18.04 & 0.88 & 0.17 \\
\hline
\end{tabular}


Fig.1 Flow diagram for preparation of custard apple soya milk shake

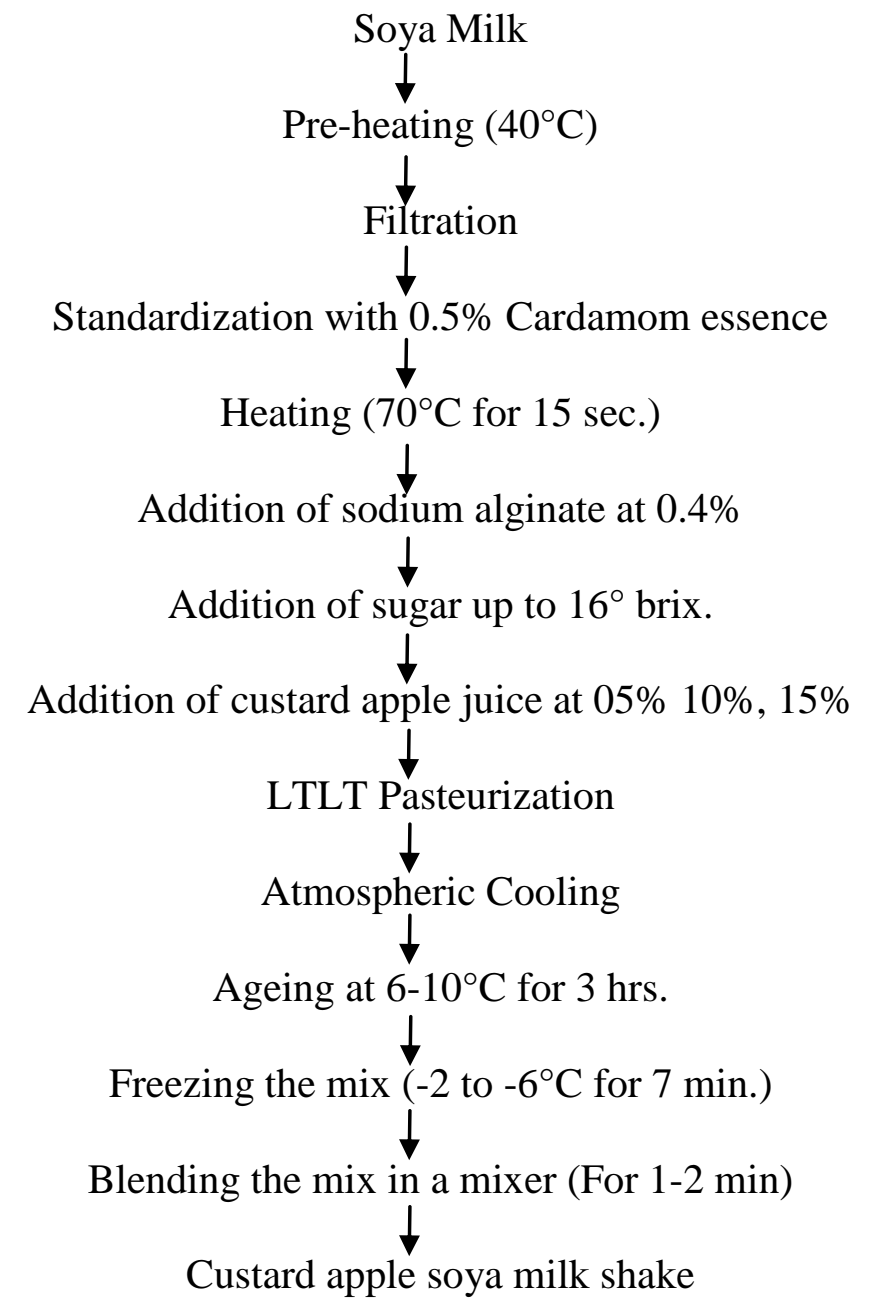

Specific gravity: Specific gravity was determined by specific gravity bottle method. The specific gravity for treatment $\mathrm{T}_{1}, \mathrm{~T}_{2}$ and $\mathrm{T}_{3}$ were $1.0624,1.0626$ and 1.0628 , respectively. The specific gravity of custard apple soya milk shake was recorded highest in $\mathrm{T}_{3}$ (1.0628) and lowest in $\mathrm{T}_{1}$ (1.0624). It was observed that as the incorporation of custard apple pulp increased with increase specific gravity of finished product.

Density: Density of treatment $\mathrm{T}_{1}, \mathrm{~T}_{2}$ and $\mathrm{T}_{3}$ were 1.1364, 1.1366 and $1.1368 \mathrm{gm} / \mathrm{ml}$, respectively. Treatment $\mathrm{T}_{3}(1.1368 \mathrm{gm} / \mathrm{ml})$ had highest value than $\mathrm{T}_{1}(1.1364 \mathrm{gm} / \mathrm{ml})$ and $\mathrm{T}_{2}$ $(1.1366 \mathrm{gm} / \mathrm{ml})$. It was observed that, the proportion of custard apple pulp was increased with increase the density of finished product.

pH: The $\mathrm{pH}$ value of treatment $\mathrm{T}_{1}, \mathrm{~T}_{2}$ and $\mathrm{T}_{3}$ were 6.30, 6.27 and 6.25 percent, respectively. The $\mathrm{pH}$ of custard apple soya milk shake was highest in treatment $T_{1}$ as compared to others. The reading shows that, the incorporation of custard apple pulp was increased with decrease the $\mathrm{pH}$ of finished product.

Chemical composition: Chemical composition of custard apple soya milk shake prepared from different parts of soya milk and 
custard apple pulp i.e. treatment $T_{1}, T_{2}$ and $T_{3}$ were studied and is shown in table 3 .

Protein: The protein content of custard apple soya milk shake for treatment $\mathrm{T}_{1}, \mathrm{~T}_{2}$ and $\mathrm{T}_{3}$ was $3.85,3.50$ and 2.80 percent, respectively. The protein content was highest in treatment $\mathrm{T}_{1}(3.85 \%)$ and lowest in treatment $\mathrm{T}_{3}$ $(2.80 \%)$. It was observed that as the proportion of custard apple pulp in the blend increased there was decrease in the protein content, which might be due to less protein content in custard apple pulp as compared to soya milk.

Fat: The fat content of treatment $T_{1}, T_{2}$ and $\mathrm{T}_{3}$ was 1.6, 1.2 and 1.0 percent, respectively. Treatment $\mathrm{T}_{1}$ content was highest fat as compared to other. The reading shows that as the addition of custard apple pulp was increased the fat content of product decreased. This might be due to low fat content in custard apple pulp as compared soya milk.

Total Sugar content: The total sugar content in treatment $T_{1}, T_{2}$ and $T_{3}$ were $15.75,16.92$ and 18.04 percent, respectively. Treatment $\mathrm{T}_{3}$ $(18.04 \%)$ content was more than sugar as compared $\mathrm{T}_{1}(15.75 \%)$ and $\mathrm{T}_{2}(16.92 \%)$. It was observed that, the proportion of custard apple pulp was increased with increased sugar content in custard apple soya milk shake. This might be due to higher sugar content in custard apple pulp.

Ash content: The ash content in custard apple soya milk shake for treatment $T_{1}, T_{2}$ and $T_{3}$ were $0.72,0.75$ and 0.88 percent, respectively. The ash content of treatment $\mathrm{T}_{3}$ was higher as compared other. It was observed that as the ash content of finished product increased with increase incorporation of custard apple pulp.

Acidity: The acidity of treatment $\mathrm{T}_{1}, \mathrm{~T}_{2}$ and $\mathrm{T}_{3}$ was $0.14,0.16$ and 0.17 percent, respectively. There was slight difference between treatments. The data shows that, the proportion of custard apple pulp was increased with increase the acidity of finish product.

The above results were supported by the results of Sharma and Gupta (1978), kadav (2001), kashid (2005) and Poul et al., (2009).

It is concluded on the basis of the above result soya milk can very well be alternative of cow or buffalo milk for preparation of custard apple soya milk shake. Treatment $T_{2}$ (90:10) was more acceptable than other treatments. The chemical analysis of custard apple soya milk shake that the presence of little amount of fat (1.2), protein (3.50), carbohydrate $(16.92 \%)$, ash $(0.75 \%)$, acidity $(0.16 \%)$ and gives higher nutritional value.

\section{References}

A.O.A.C. 1990. Official Methods of Analysis. $15^{\text {th }}$ Edition, Washington D. C., Assoc. Analytical Chemists, 1546.

Akintunde, T.T.Y. and Akintunde, B.O. 2002. Development of Models for Predicting the Yield and Quality of Soymilk. J. Food Technol. Africa, 7: 55-58.

Beerh, O.P. et al. 1983. Indian Food Packer, 37(3): 19-21.

FSSAI. 2001. Manual of Methods of Analysis of Foods. Milk and Milk Products. Food Safety and Standards Authority of India Ministry of Health and Family Welfare Government of India, New Delhi, Lab. Manual-1.

ISI 1961. IS:1479. Determination of Total solids and ash. Part-II, Indian Standards Institution. Manak Bhavan, New Delhi.

Jooyandeh, H. 2011. Soy Products as Healthy and Functional Foods. Middle-East J. Scientific Res., 7(1): 71-80, ISSN 19909233.

Kadav, V.B. 2001. Preparation of fruit 
flavoured milk shake. M.Sc. (Ag.) Thesis, Dr. Balashed Sawant Konkan Krishi Vidyapeeth, Dapoli, Dist. Ratnagiri (M.S.).

Kashid, U.B. 2005. Preparation of Golden milk shake from cow milk blended with safflower milk. M.Sc. (Ag.) Thesis, Marathwada Agricultural University, Parbhani.

Kirtikar, K.R. and Basu S.D. 1955. Indian Medicinal Plants. Lalit Mohan Basu., Allahabad, India, pp 66-68.

Kwok, K.C. and Niranjan, K. 1995. Review: Effect of Thermal Processing on Soymilk. Int. J. Food Sci. Technol., 30: 263-295.

Lakshmanan, R., De Lamballerie, M., and Jung, S. 2006. Effect of Soybean- to- Water Ratio and $\mathrm{pH}$ on Pressurized Soymilk Properties. J. Food Sci., 71: E384-E391.

Liu, K. 1997. Soybeans: Chemistry, Technology, and Utilization. Chapter 4. I: Soymilk \& II: Tofu. New York: Chapman and Hall. p. 138-197.

Mullin, W.J., Fregeau-Reid, J.A., Butler, M., Poysa, V., Woodrow, L., Jessop, D.B., and Raymond, D. 2001. An interlaboratory test of a procedure to assess soybean quality for soymilk and tofu production. Food Res. Int., 34: 669-
677.

Oloye, D.A. 2014. The Effects of Different Processing Techniques on the Organoleptic Quality of Soymilk Processing and Storage. Research and Reviews: J. Food and Dairy Technol., Vol.-2 Issue-2: 9.

Poul, S.P., Sontakke, A.T., Munde, S.S. and Adangale, A.B. 2009. Compostion and Economics of Custard Apple Milk Shake, The Asian J. Animal Sci., vol.-4 issue-2: 139-149.

Poul, S.P., Sontakke, A.T., Munde, S.S., Adangale, A.B. and Jadhav, P.B., 2009. Process Standardisation for Custard Apple Milk Shake. J. Dairying, Foods \& H.S., 28 (3/4): 202-205.

Ranganna S. 1999. Handbook Of Analysis And Quality Control For Fruits And Vegetables Products. Second Edn, Tata Mcgraw-Hill Publishing Company Limited New Delhi.

Rao, S.N. 1974. Annona the legendary fruit. Indian Hort., 18:19-20.

Sharma, A.K. and Gupta, S.K. 1978. Manufacture of milk shake. Indian Dairyman, 30(8): 585.

Thimmaiah, S. 2012. Standard Methods Of Biochemical Analysis, Kalyani Publishers, ISBN 81-7663-067-5.

\section{How to cite this article:}

Ramesh Avhad, Vaibhav Patil and Navnath Sarode. 2017. Standardization and PhysicoChemical Properties of Custard Apple Soya Milk Shake. Int.J.Curr.Microbiol.App.Sci. 6(2): 1811-1817. doi: http://dx.doi.org/10.20546/ijcmas.2017.602.203 